the pathophysiology of edema formation. In: Brenner BM, Rector FC (eds): The Kidney. Philadelphia, WB Saunders Co, pp 495-522

16. Dixon TF, Purdom M 1954 Serum 5-nucleotidase. J Clin Pathol 7:341

17. Friedman AL, Albright PW, Chesney RW 1981 Dietary adaptation of taurine transport by rat renal epithelium. Life Sci 29:2415

18. Friedman AL, Jax DK, Chesney RW 1981 Developmental aspects of renal $\beta$ amino acid transport. III. Characteristics of transport in isolated renal tubules. Pediatr Res 15:10

19. Friedman AL, Albright PW, Gusowski N, Padilla M, Chesney RW 1983 Renal adaptation to alteration in dietary amino acid intake. Am J Physiol 245:F159

20. Glossman H, Neville DM, Jr $1972 \gamma$-Glutamyltransferase in kidney brush border membranes. FEBS Lett 19:340

21. Hilden SA, Sacktor B 1978 Preservation of renal brush border membrane transport function by storage in glycerol. Kidney Int 14:279

22. Huxtable RJ 1981 Insights on function: metabolism and pharmacology of taurine in the brain. In Lombardini JB, Kenney AD. (eds): The Role of Peptides and Amino Acids as Neurotransmitters, New York, Alan R. Liss Inc, pp 53-97

23. Kildovsky O 1971 Developmental changes of $\beta$-galactosidase and $\beta$-glucuronidase in the rat liver and kidney. Arch Biochem Biophys 142:378

24. Kunin CM, Chesney RW 1978 Enzymuria as a marker of renal injury and disease: studies of $N$-acetyl- $\beta$-glucosamidase in defined renal diseases of childhood. Pediatrics 62:751

25. Lowry OH, Rosebrough NJ, Farr AL, Randall RJ 1951 Protein measurement with the Folin phenol reagent. J Biol Chem 193:265

26. Lowry OH, Passonneau JV 1972 A Flexible System of Enzymatic Analysis. New York, Academic Press, pp 201-204

27. Neal JL 1972 Analysis of Michaelis kinetics for two independent saturable membrane transport functions. J Theor Biol 35:113

28. Post RL, Sen AK 1981 Sodium and potassium-stimulated ATPase. Methods Enzymol 10:762

29. Robillard JE, Sessions C, Kennedy RL, Smith FG, Jr 1978 Maturation of the glucose transport process by the fetal kidney. Pediatr Res 12:680
30. Roth KS, Hwang SM, Yudkoff M, Segal S 1978 The ontogeny of sugar transport in kidney. Pediatr Res 12:1127

31. Rozen R, Tenenhouse HS, Scriver CR 1979 Taurine transport in renal brush border membrane vesicles. Biochem J 180:245

32. Rozen R, Scriver CR 1982 Renal transport of taurine adapts to perturbed taurine homeostasis. Proc Natl Acad Sci USA 79:2101

33. Segal S 1982 Regulatory aspects of transport during development. In: Spitzer A (ed): The Kidney during Development: Morphology and Function. New York, Masson Publishing, p 363

34. Seigle R, Kinne R, Spitzer A 1982 Glucose transport in newborn guinea pig brush border membrane fragments. Kidney Int 21:287A

35. Sottocassa GL, Kuylenstierna B, Ernster L 1967 An electron transport system associated with the outer membrane of liver mitochondria: a biological and morphological study. J Cell Biol 32:415

36. Steele TH, DeLuca HF 1976 Influence of the dietary phosphorus on renal phosphate reabsorption in the parathyroidectomized rat. J Clin Invest 57:867

37. Trohler J, Bonjour JP, Fleisch H 1976 Inorganic phosphate homeostasis: renal adaptation to the dietary intake in intact and thyroparathyroidectomized rats. J Clin Invest 57:264

38. Tudvad F 1949 Sugar reabsorption in premature and full-term babies. Scand $\mathrm{J}$ Clin Lab Invest 1:281

39. Wen GY, Sturman JA, Wisniewski HM, Lidsky AA, Cornwell AC, Hayes KC 1979 Tapetum disorganization in taurine-depleted cats. Invest Ophthalmol Visual Sci 18:1201

40. This research was supported by funds from the Medical School and Graduate School Research Committees, University of Wisconsin. Dr. Chesney is the recipient of Research Career Development Award, KO4-AM00421 from the National Institutes of Health.

41. Requests for reprints should be addressed to: Russell W. Chesney, M.D., Department of Pediatrics, University of Wisconsin Hospitals, 600 Highland Avenue, Madison, WI 53792.

42. Received for publication December 13, 1982

43. Accepted for publication August 10, 1983.

\title{
Effects of Nitroprusside on Cardiac Function, Blood Flow Distribution, and Oxygen Consumption in the Conscious Young Lamb
}

\author{
JAAP R. G. KUIPERS, ${ }^{(34)}$ DANIEL SIDI, ${ }^{(35)}$ MICHAEL A. HEYMANN, AND \\ ABRAHAM M. RUDOLPH ${ }^{(36)}$ \\ Cardiovascular Research Institute and the Departments of Pediatrics, Physiology, and Obstetrics, Gynecology \\ and Reproductive Sciences, University of California, San Francisco, California USA
}

\begin{abstract}
Summary
Resting cardiac output is high relative to body weight during the neonatal period and there is a limited reserve for further increasing cardiac output. We assessed the effect on the circulation of reducing peripheral vascular resistance by infusing high doses of sodium nitroprusside in 1- and 3-week-old lambs. In a dose of $5 \mu \mathrm{g} \cdot \mathrm{kg}^{-1} \cdot \mathrm{min}^{-1}$ over $1 \mathrm{~h}$, nitroprusside caused a decrease in aortic and left atrial pressure, an increase in heart rate, and no significant changes in cardiac output or oxygen consumption. Infusing $10 \mu \mathrm{g} \cdot \mathrm{kg}^{-1} \cdot \mathrm{min}^{-1}$ for $2 \mathrm{~h}$ resulted in an initial marked decrease in aortic pressure, cardiac output, and also heart rate. Within $\mathbf{5 0}$ min aortic pressure gradually increased, but was still well below control levels, while cardiac output returned to control level and heart rate slowly increased. Distribution of cardiac output and organ blood flows was measured by the radionuclide microsphere method. Blood flows to the kidneys and to the skin
\end{abstract}

fell markedly, but flows to other organs did not change significantly.

Sodium nitroprusside has been shown to be beneficial in the medical management of patients with acute or chronic heart failure $(1,8,10,20,21,24)$. Positive effects were attributed to a reduction in systemic vascular impedance or left ventricular afterload caused by arteriolar vasodilatation and to a reduction in preload secondary to venodilatation (29). Reduction in preload, however, can also result from the additional effects of nitroprusside on myocardial relaxation (6), left ventricular diastolic properties (7), and alterations in pulmonary venous compliance (32). The precise mechanisms by which nitroprusside alters the hemodynamics in physiological and pathological situations are still not completely understood; yet nitroprusside is widely used clinically. Experience with nitroprusside in the pe- 
diatric age group, however, is limited and there is, as yet, no reliable information concerning its effectiveness $(2,3)$. In view of our observations that, in the neonate, resting cardiac output is high, and systemic vascular resistance is relatively low, we wondered what effects nitroprusside would have in the newborn animal.

The objectives of this study were to assess the influence of postnatal age on the response to nitroprusside, and to examine the changes in distribution of the cardiac output caused by nitroprusside.

\section{MATERIALS AND METHODS}

Nineteen lambs of mixed Western breed and documented birth dates were studied. They were divided into two groups; group 1 ( 7 lambs) was studied between 4 and 8 days (mean, 5.9 days), and group 2 (12 lambs) from 19 to 28 days (mean, 22.6 days). Throughout the study, each lamb remained with its mother and fed well.

Surgical procedures: thoracotomy. Surgical preparation, catheter care, and antibiotic administration were carried out in the 19 lambs as described previously (15). Briefly, under halothane anesthesia $\left(0.5 \%\right.$ in $\left.\mathrm{O}_{2}\right)$, the lambs were ventilated by a Harvard pump. A left thoracotomy was performed in the third or fourth intercostal space; polyvinyl catheters (OD $1.2 \mathrm{~mm}$; ID $0.75 \mathrm{~mm}$ ) were passed from the internal thoracic artery and vein into the aorta and superior vena cava, respectively. The pericardium was incised over the main pulmonary artery to within $2-3 \mathrm{~mm}$ of the vagus nerve. Similar catheters were inserted through purse string sutures into the pulmonary artery and through the left atrial appendage into the body of the left atrium. A precalibrated electromagnetic 7-13 mm flow transducer (C. C. Instruments, Culver City, CA) was placed around the ascending aorta just above the coronary arteries. The ductus arteriosus was examined to ascertain that it was closed; in two of the younger lambs, it had to be ligated. An $8 \mathrm{~F}$ polyvinyl catheter was placed in the left pleural cavity for drainage. No attempt was made to close the pericardium. All catheters and the flow transducer cable were led to the skin on the left flank and protected by a Teflon cloth pouch which was sewn to the skin after the chest had been closed in layers. Air and fluid were withdrawn from the chest.

Through a small incision in the left leg, polyvinyl catheters were passed into the femoral artery and vein. These catheters were protected by a bandage around the leg. All catheters except the one for chest drainage were filled with heparin (1000 units. $\mathrm{ml}^{-1}$ ) and plugged.

On the day of surgery and on days 1-4 postoperatively, we injected 100,000 units $\cdot \mathrm{kg}^{-1}$ of procaine penicillin and $50 \mathrm{mg}$. $\mathrm{kg}^{-1}$ of dihydrostreptomycin intramuscularly. The heparin was drained from the catheters daily, after which they were flushed with $0.9 \%$ saline and refilled with heparin. We allowed the lambs at least 3 days to recover from surgery before we started our studies.

Experimental Protocols. Control protocol. The lambs were allowed to feed until $1 \mathrm{~h}$ prior to study. At that time they were placed in a canvas sling which supported them in an upright position. The lambs were not sedated but were blindfolded to help keep them calm. A loose mask was placed over each lamb's head to collect the mixed expired gas that was used to measure oxygen consumption by the flow-through system, as described previously (18). Data were collected only when the lambs were calm and resting. During the control period oxygen consumption, aortic blood flow minus coronary blood flow, aortic, pulmonary arterial, left atrial and central venous pressures, and heart rate were measured continuously. One-ml blood samples were withdrawn from the aorta to determine blood gases, $\mathrm{pH}$, hemoglobin concentration, and $\mathrm{O}_{2}$ saturation. Three to 5 min later, radionuclide-labeled microspheres were injected into the left atrium in all group 1 lambs and in 9 group 2 lambs. Since ambient temperature influences oxygen consumption and car- diovascular function both at rest and during stress (28), during the study we kept ambient temperature between $22-25^{\circ} \mathrm{C}$, depending on the age of the lamb.

Nitroprusside protocol. After taking control measurements for 20-45 min (mean, $30 \mathrm{~min}$ ), we infused nitroprusside in quantities of 5 and $10 \mu \mathrm{g} \cdot \mathrm{kg}^{-1} \cdot \mathrm{min}^{-1}$ for 1 to $2 \mathrm{~h}$, respectively. From the onset of infusion, it took about 2-3 min to fill the catheter with nitroprusside. We measured the same variables as during the control period. Blood samples were drawn at 10 and $50 \mathrm{~min}$ while microspheres, if used, were injected at 10 and/or $50 \mathrm{~min}$ after the onset of infusion. At the end of the study, the lamb was anesthetized with an intravenous injection of sodium pentobarbital and killed.

Nitroprusside $\left(5 \mu g \cdot \mathrm{kg}^{-1} \cdot \mathrm{min}^{-1}\right)$. Five lambs were studied from each age group. For technical reasons, oxygen consumption could be measured in only three lambs from group 1 . Radioactive microspheres were used only in group 1. After the infusion, we studied the lambs during a 30-min recovery period.

Nitroprusside $\left(10 \mu \mathrm{g} \cdot \mathrm{kg}^{-1} \cdot \mathrm{min}^{-1}\right)$. We studied 7 lambs in group 1 and 12 lambs in group 2 . Radioactive microspheres were injected at 10 and $50 \mathrm{~min}$ in all group 1 lambs and in 9 group 2 lambs. Because of technical problems and also with a view to other studies, measurements were made for only $2 \mathrm{~h}$ in 8 group 2 lambs. In these 8 lambs and in 6 group 1 lambs, oxygen consumption was measured. All group 1 and the 8 group 2 lambs were studied for $60 \mathrm{~min}$ after the infusion was stopped.

Measurements and calculations. Oxygen consumption was measured continuously by the flow-through system as described previously (18). Aortic blood flow minus coronary blood flow was measured with a precalibrated electromagnetic flow transducer connected to a Statham SP 2202 flowmeter. Aortic, pulmonary arterial, left atrial, and systemic venous pressures were measured with Statham P23Db pressure transducers. Heart rate was calculated from the aortic blood pressure or flow signal with a cardiotachometer. All these variables were recorded on a Beckman type RM direct-writing recorder. Blood gas tensions and $\mathrm{pH}$ were measured with a Radiometer blood gas analyzer with appropriate electrodes; hemoglobin concentration and blood oxygen saturation were measured with a Radiometer OSM-2 hemoximeter. Cardiac output and flow distribution were measured with $15-\mu \mathrm{m}$ diameter radionuclide-labeled microspheres (11). As microspheres were injected into the left atrium, reference samples from the ascending and descending aorta were continuously and simultaneously drawn into preweighed syringes for 1 to $1.25 \mathrm{~min}$ at a rate of $7 \mathrm{ml} \cdot \mathrm{min}^{-1}$. After killing the lambs, we dissected them as described previously (11). The heart was weighed, fixed in $10 \%$ formalin for 7 days, and then reweighed. The atria, great vessels, valves and chordae, and epicardial fat were removed. The right and left ventricular free walls and septum were separated and divided into three transmural layers. The different parts of the heart, organs, and tissues were incinerated in an oven; their radioactivity was determined in a 1000 -channel pulse height analyzer (Inotech Inc., Fort Atkinson, WI) (11). Blood flow to the various organs and regional myocardial blood flow were calculated with the aid of a IBM 370 computer. Cardiac output was measured by determining radioactive counts of the entire animal. The weight of each tissue sample of the heart was corrected for weight change caused by fixation. Myocardial, organ, and tissue blood flows were expressed as flow $/ 100 \mathrm{~g}$ of fresh weight $\left(\mathrm{ml} \cdot \mathrm{min}^{-1} \cdot 100 \mathrm{~g}^{-1}\right)$. The transmural distribution of left ventricular myocardial blood flow was determined by dividing blood flow to the subendocardial layer by flow to the subepicardial layer of the left ventricle, to give the endo:epi flow ratio. The systemic vascular resistance was calculated by dividing the mean aortic pressure minus central venous pressure by the left ventricular output in liters $\cdot \mathrm{min}^{-1}$, and the vascular resistance of a particular vascular bed was obtained by dividing the pressure difference at the time of microsphere injection by the blood flow to that organ or tissue expressed as $\mathrm{ml} \cdot \mathrm{min}^{-1} \cdot 100 \mathrm{~g}^{-1}$.

Statistical Analysis. Results are expressed as the mean $\pm \mathrm{SE}$. 
Within each group, the data obtained during the control period before infusion of $5 \mu \mathrm{g} \cdot \mathrm{kg}^{-1} \cdot \mathrm{min}^{-1}$ nitroprusside were compared with those obtained before infusion of $10 \mu \mathrm{g} \cdot \mathrm{kg}^{-1} \cdot \mathrm{min}^{-1}$ nitroprusside, and analyzed with a one-way analysis of variance to determine whether a given variable was different during the control periods. Subsequently, control data of group 2 were compared with those of group 1 and analyzed by one-way analysis of variance (31). Two-way analysis of variance with replication and unequal samples was used within each group to test the response to nitroprusside, the effect of the different concentrations, and their interaction. The same analysis was done to test the response to the infusion of nitroprusside of the same concentration, the effect of age, and their interaction (29). If there was a significant difference, the Neuman-Keuls test was used. A value of 0.05 was considered significant.

\section{RESULTS}

Control Period. The weights, ages, and control hemodynamic data for the two groups are shown in Table 1. There was no difference within each group between the control values obtained before the studies with $5 \mu \mathrm{g} \cdot \mathrm{kg}^{-1} \cdot \mathrm{min}^{-1}$ and those obtained before the $10 \mu \mathrm{g} \cdot \mathrm{kg}^{-1} \cdot \mathrm{min}^{-1}$ nitroprusside infusion. Between the groups we found differences in some resting cardiovascular, hematologic, and blood gas variables, as described previously by Lister et al. (19) (Table 1). The cardiac output and oxygen consumption per $\mathrm{kg}$ body weight and heart rate were significantly lower in group 2 than in group 1.

Cardiac output measured by radionuclide-labeled microspheres was, as expected, higher than that measured by the electromagnetic flow transducer (16) both in group 1 (291 \pm 18 , $P<0.05)$ and group $2\left(228 \mathrm{ml} \cdot \mathrm{kg}^{-1} \cdot \mathrm{min}^{-1}, P<0.05\right)$. The proportion of cardiac output distributed to the bones and to the carcass, as well as the blood flows/100 g tissue, was significantly lower in group 2 (bones, $P<0.05$; carcass, $P<0.025$ ). The percentage of cardiac output to the kidneys, however, was significantly higher in group 2 than in group $1(P<0.005)$; actual flow $/ 100 \mathrm{~g}$ to the kidney was not significantly different in the two groups. Otherwise, there were no significant differences in distribution or cardiac output or organ blood flow between the two groups in the initial control period.

Responses to nitroprusside. The time sequence of the responses to the infusion of 5 or $10 \mu \mathrm{g} \cdot \mathrm{kg}^{-1} \cdot \mathrm{min}^{-1}$ nitroprusside was similar in the two age groups (Figs. 1 and 2). About 2 to 3 min after the

Table 1. Control values*

\begin{tabular}{lcc}
\hline & Group 1† & Group 2\$ \\
\hline Heart rate $\left(\right.$ beats $\left.\cdot \mathrm{min}^{-1}\right)$ & $212 \pm 9$ & $173 \pm 10^{a}$ \\
Mean aortic pressure $(\mathrm{mm} \mathrm{Hg})$ & $75 \pm 3$ & $77 \pm 3$ \\
Left atrial pressure $(\mathrm{mm} \mathrm{Hg})$ & $1.3 \pm 0.4$ & $2.4 \pm 0.4$ \\
Aortic blood flow $\left(\mathrm{ml} \cdot \mathrm{min}^{-1} \cdot \mathrm{kg}^{-1}\right) \S$ & $252 \pm 16$ & $193 \pm 6^{6}$ \\
Stroke volume $\left(\mathrm{ml} \cdot \mathrm{kg}^{-1}\right)$ & $1.18 \pm 0.05$ & $1.16 \pm 0.09 \pi$ \\
Systemic vascular resistance & $48 \pm 4$ & $54 \pm 3 \pi$ \\
$\left.\quad \quad \quad \mathrm{mm} \mathrm{Hg}\left(\text { liters } \cdot \mathrm{min}^{-1}\right)^{-1}\right]$ & $14.2 \pm 0.6 \|$ & $9.3 \pm 0.4^{c}$ \\
Oxygen consumption & & \\
$\quad\left(\mathrm{ml} \cdot \mathrm{kg}^{-1} \cdot \mathrm{min}^{-1}\right)$ & $7.43 \pm 0.1$ & $7.43 \pm 0.01$ \\
$\mathrm{pH}$ & $75 \pm 4$ & $84 \pm 3$ \\
$\mathrm{PO}_{2}(\mathrm{~mm} \mathrm{Hg})$ & $38 \pm 1$ & $38 \pm 1$ \\
$\mathrm{PCO}_{2}(\mathrm{~mm} \mathrm{Hg})$ & $93 \pm 1$ & $93 \pm 1$ \\
$\mathrm{O}_{2}$ saturation $(\%)$ & $8.7 \pm 0.7$ & $6.9 \pm 0.5$ \\
$\mathrm{Hemoglobin}\left(\mathrm{g} \cdot \mathrm{dl}^{-1}\right)$ & 7 & 12 \\
$n$ &
\end{tabular}

* Data shown are means $\pm \mathrm{SE}$. One-way analysis of variance: $v s$. group I: ${ }^{a}, P<0.05 ;{ }^{b}, P<0.005 ;{ }^{c}, P<0.001$.

$\dagger$ Weight, $6.5 \pm 0.6 \mathrm{~kg}$; age, $5.9 \pm 0.7$ days.

$\ddagger$ Weight, $7.3 \pm 0.3 \mathrm{~kg}$; age, $22.6 \pm 0.7$ days

$\S$ Measured by electromagnetic flow probe.

I $n=11$.

$\| n=6$. onset of infusion, mean aortic pressure fell consistently, but changes in heart rate, cardiac output, and left atrial pressure fluctuated for about $15 \mathrm{~min}$. There was then a gradual adjustment and by $50 \mathrm{~min}$ after the onset of infusion all the hemodynamic variables were stable until the end of the infusion.

The fall in mean aortic blood pressure reached its nadir 5 to 7 min after the onset of the infusion in both groups 1 and 2 , amounting to 70 and $50 \%$ of the control value, respectively. During $5 \mu \mathrm{g} \cdot \mathrm{kg}^{-1} \cdot \mathrm{min}^{-1}$ nitroprusside, the pressure decreased significantly from $75 \pm 4$ to $53 \pm 5 \mathrm{~mm} \mathrm{Hg}(P<0.025)$ in group 1 and from $84 \pm 3$ to $59 \pm 4 \mathrm{~mm} \mathrm{Hg}(P<0.001)$ in group 2 . During $10 \mu \mathrm{g} \cdot \mathrm{kg}^{-1} \cdot \mathrm{min}^{-1}$ nitroprusside, there was a decrease from $75 \pm 3$ to $35 \pm 4 \mathrm{~mm} \mathrm{Hg}$ and from $79 \pm 4$ to $39 \pm 2 \mathrm{~mm}$ $\mathrm{Hg}(P<0.001)$, respectively. The minimum pressures obtained during 5 and $10 \mu \mathrm{g} \cdot \mathrm{kg}^{-1} \cdot \mathrm{min}^{-1}$ nitroprusside differed significantly $(P<0.001)$ in group 2 only. After the maximum decrease, the mean aortic pressure gradually increased to $62 \pm 6 \mathrm{~mm} \mathrm{Hg}$ with $5 \mu \mathrm{g} \cdot \mathrm{kg}^{-1} \cdot \mathrm{min}^{-1}$ nitroprusside, and to $57 \pm 3 \mathrm{~mm} \mathrm{Hg}$ with the higher infusion rate in group 1 animals. In group 2, it increased to $72 \pm 6$ and $67 \pm 2 \mathrm{~mm} \mathrm{Hg}$, respectively. These values were all still significantly lower than the control values except for group 1 during $5 \mu \mathrm{g} \cdot \mathrm{kg}^{-1} \cdot \mathrm{min}^{-1}$ nitroprusside. After the infusion was stopped, mean aortic pressure increased significantly in group 1 to $86 \pm 6(P<0.025)$ and $83 \pm 4(P<0.001)$ $\mathrm{mm} \mathrm{Hg}$ and in group 2 to $91 \pm 4(P<0.005)$ and $92 \pm 3(P<$ $0.001) \mathrm{mm} \mathrm{Hg}$, respectively. In both the 5 and $10 \mu \mathrm{g} \cdot \mathrm{kg}^{-1} \cdot \mathrm{min}^{-1}$ nitroprusside studies, there were no significant differences between groups 1 and 2 in the pressures obtained at corresponding times before, during, and after the nitroprusside infusion.

Mean left atrial pressure was slightly lower during nitroprusside infusion in both groups 1 and 2, but the values were not significantly different from control. After the infusion was stopped at $10 \mu \mathrm{g} \cdot \mathrm{kg} \cdot \mathrm{min}^{-1}$, mean left atrial pressure rose to $3.8 \pm 0.8 \mathrm{~mm}$ $\mathrm{Hg}$ in group $1(P<0.025)$, and to $6.9 \pm 1.0 \mathrm{~mm} \mathrm{Hg}$ in group 2 $(P<0.001)$, levels significantly higher than the pressures during both infusion and control periods.

Heart rate increased immediately after the onset of nitroprusside infusion in both groups. With the $5 \mu \mathrm{g} \cdot \mathrm{kg}^{-1} \cdot \mathrm{min}^{-1}$ infusion rate, it increased by about $22 \%$ within $3 \mathrm{~min}$; this rate was maintained throughout the infusion, but heart rate fell rapidly after the infusion was stopped. With the $10 \mu \mathrm{g} \cdot \mathrm{kg}^{-1} \cdot \mathrm{min}^{-1}$ infusion, the heart rate also increased within $3 \mathrm{~min}$ from $212 \pm$ 9 to $267 \pm 10(P<0.001)$ in group 1 , and from $157 \pm 8$ to 192 $\pm 8(P<0.05)$ in group 2 ; both represented a $25 \%$ rise. Heart rate then fell rapidly (within $3-5 \mathrm{~min}$ ) to $84 \%$ of control in group 1 and to control in group 2, and again increased, but gradually (within $60 \mathrm{~min}$ ) to reach a peak of $282 \pm 8(P<0.001)$ in group 1 and $209 \pm 5(P<0.005)$ in group 2 ; these levels were maintained until the end of the infusion when heart rate rapidly fell to control values.

Cardiac output, as measured with the electromagnetic flowmeter (thus excluding coronary blood flow), decreased rapidly after the onset of the nitroprusside infusion, reaching a nadir after $10 \mathrm{~min}$. With the $5 \mu \mathrm{g} \cdot \mathrm{kg}^{-1} \cdot \mathrm{min}^{-1}$ infusion rate, the fall in cardiac output was not statistically significant, nor was it significant with the higher infusion rate in group 2. In group 1 animals, however, the early fall in cardiac output was significant $(P<$ $0.005)$ : from $252 \pm 16$ to $162 \pm 18 \mathrm{ml} \cdot \mathrm{kg}^{-1} \cdot \mathrm{min}^{-1}$, a fall of $36 \%$. Cardiac output then increased gradually, returning to control values in 50 to $60 \mathrm{~min}$.

Systemic vascular resistance did not change significantly during infusion of $5 \mu \mathrm{g} \cdot \mathrm{kg}^{-1} \cdot \mathrm{min}^{-1}$ nitroprusside in either group. During infusion of $10 \mu \mathrm{g} \cdot \mathrm{kg}^{-1} \cdot \mathrm{min}^{-1}$, the vascular resistance fell significantly immediately after onset of the infusion in both groups, reaching a nadir in about $5 \mathrm{~min}$, to $62 \%$ of control values. Following this, resistance returned to control levels in about 20 min, then fell again to about $77 \%$ of control; this fall was significant only in group 2 . After the infusion was stopped, systemic vascular resistance increased abruptly and then returned to control levels.

Oxygen consumption was, as reported previously, considerably 

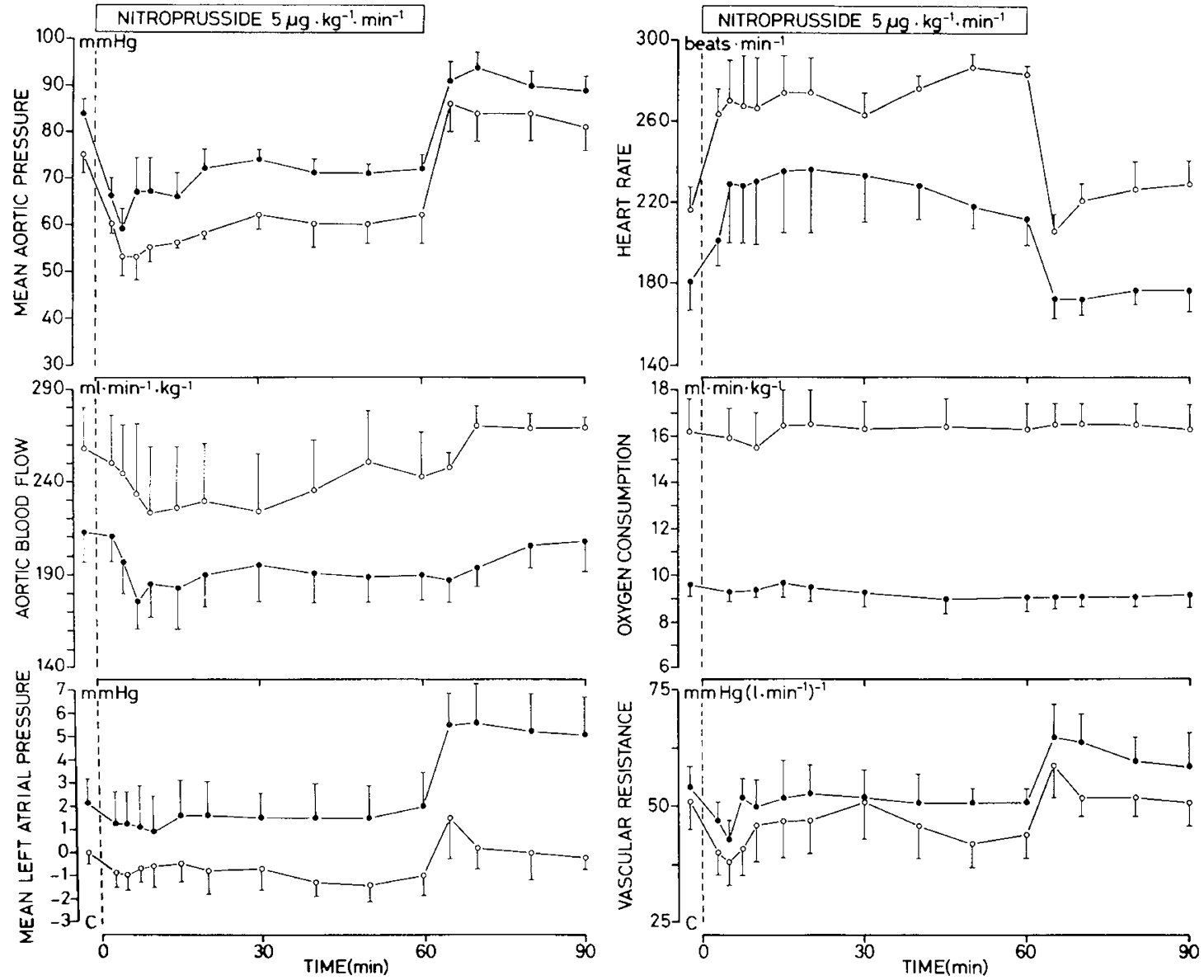

Fig. 1. Sequential effects of a 1-h I.V. infusion of $5 \mu \mathrm{g} \cdot \mathrm{kg}^{-1} \cdot \mathrm{min}^{-1}$ of sodium nitroprusside, followed by a 30 -min recovery period, on mean aortic pressure, aortic blood flow, mean left atrial pressure, heart rate, oxygen consumption, and vascular resistance in newborn $(O)$ and 3-week-old lambs $(\bullet)$. Data are means $\pm \mathrm{SE}$ of five experiments, except for the oxygen consumption of the newborn lambs where there were three. $C$, control (pre-infusion).

higher in group 1 as compared with group 2 lambs. Infusing 5 $\mu \mathrm{g} \cdot \mathrm{kg}^{-1} \cdot \mathrm{min}^{-1}$ nitroprusside did not significantly alter oxygen consumption; infusing $10 \mu \mathrm{g} \cdot \mathrm{kg}^{-1} \cdot \mathrm{min}^{-1}$ did not change oxygen consumption in group 2 but oxygen consumption fell significantly in group 1 animals. Oxygen consumption gradually returned to control levels within $60 \mathrm{~min}$ after onset of the infusion.

Distribution of Cardiac Output and Organ Blood Flows. During infusion of $5 \mu \mathrm{g} \cdot \mathrm{kg}^{-1} \cdot \mathrm{min}^{-1}$ nitroprusside, distribution of cardiac output was examined only in the younger (group 1) animals (Table 2). The only significant changes noted were in the kidneys and the brain. The proportion of cardiac output, and actual blood flow, to the kidney fell. Renal blood flow dropped from $345 \pm 31$ to $213 \pm 22 \mathrm{ml} \cdot \mathrm{min}^{-1}(P<0.025), 10 \mathrm{~min}$ after infusion. Renal vascular resistance, however, did not change significantly. Although actual cerebral blood flow did not increase significantly, cerebral vascular resistance decreased (from $1.00 \pm 0.15$ to $\left.0.63 \pm 0.09 \mathrm{~mm} \mathrm{Hg} \cdot 100 \mathrm{~g}^{-1} \cdot \mathrm{min}^{-1}\right) 50 \mathrm{~min}$ after infusion.

Infusing $10 \mu \mathrm{g} \cdot \mathrm{kg}^{-1} \cdot \mathrm{min}^{-1}$ decreased renal blood flow; in group 1 (Table 3) it was $38 \%$ of control at 10 min and $71 \%$ of control at $50 \mathrm{~min}$ after the infusion was started, and in group 2 (Table 4) it was 53 and $68 \%$ of control values at similar periods. The proportion of cardiac output to the kidneys fell significantly in both groups, but renal vascular resistance increased significantly only in group 1 animals 10 min after infusion. Blood flow to the skin fell significantly in both groups to $55-60$ and $70 \%$ of control at 10 and $50 \mathrm{~min}$, respectively. Flow to bone and total carcass fell at $10 \mathrm{~min}$ in group 1 , but returned to control at 50 min. The percentage of cardiac output to the skin decreased significantly in both groups.

Although actual adrenal blood flow did not change signifi- cantly, adrenal vascular resistance fell in group 1. Also cerebral vascular resistance fell significantly after 50 -min infusion in group 1 animals.

Myocardial blood flow and coronary vascular resistance did not change significantly in either group and the ratio of coronary blood flow to the inner and outer layers of the myocardium also did not change significantly.

\section{DISCUSSION}

Sodium nitroprusside has been used to reduce vascular resistance, or the afterload on the left ventricle, in patients with impaired ventricular performance; it has generally been administered when cardiac output is decreased (1,7-9). During the neonatal period, cardiac output is high relative to body weight $(15,19)$. In infants with left-to-right shunt lesions associated with cardiac failure, such as ventricular septal defect or patent ductus arteriosus, left ventricular output is usually increased, or at least maintained. Nitroprusside infusion has resulted in varying degrees of improvement in infants and children with ventricular septal defects (2). In the early postnatal period, the effectiveness of nitroprusside could be influenced by the relatively high cardiac output and the relatively low vascular resistance, in relation to body weight. To assess whether these developmental differences influence the responses to nitroprusside, we infused the drug into lambs at different postnatal ages. The dose we used was somewhat higher than that generally used in clinical practice. We specifically selected the dose that produced a definite decrease in systemic arterial pressure, and also examined the effects of a dose double that amount.

Heart rate has been reported to increase immediately after the 

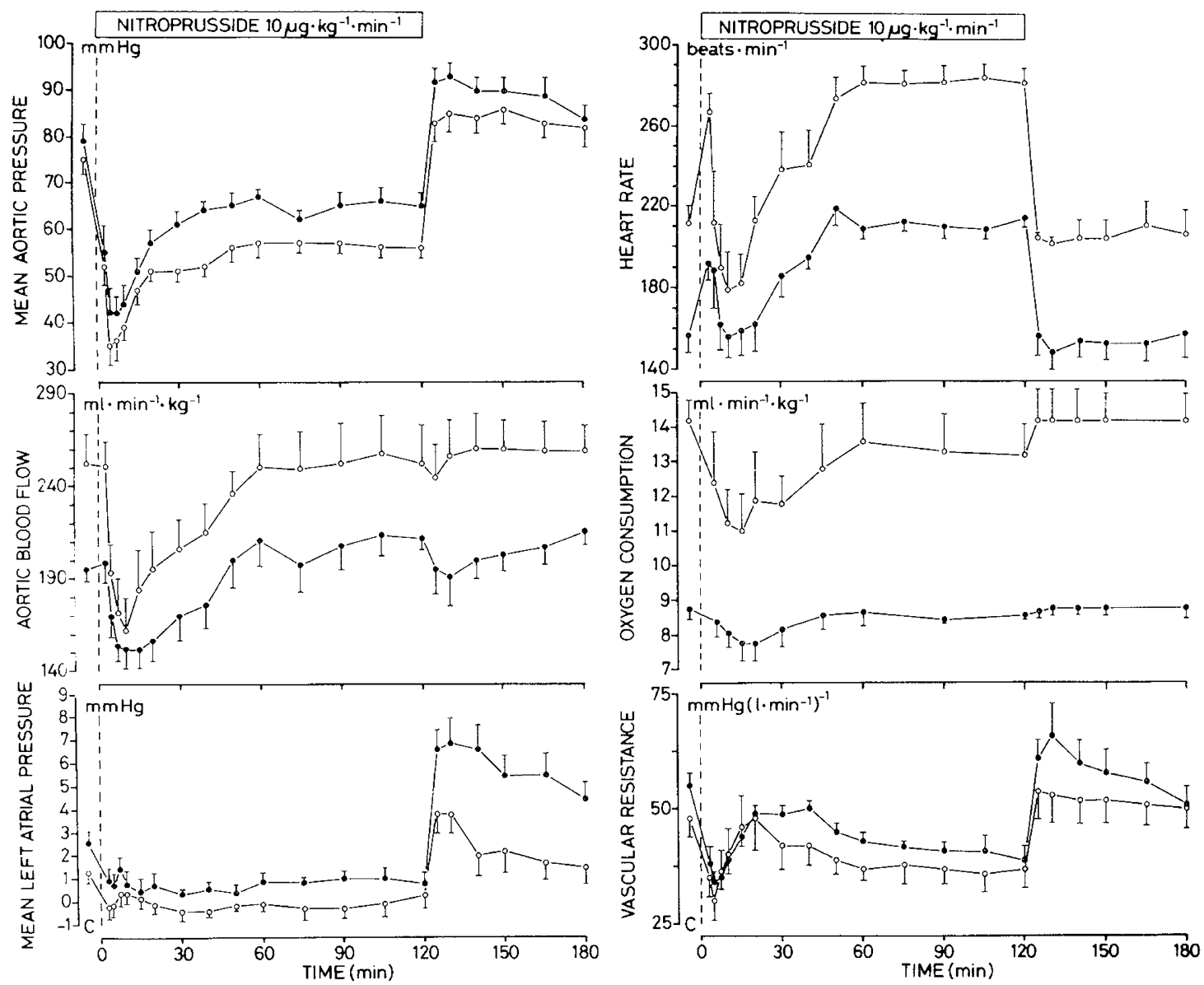

Fig. 2. Sequential effects of a 2 -h IV infusion of $10 \mu \mathrm{g} \cdot \mathrm{kg}^{-1} \cdot \mathrm{min}^{-1}$ of sodium nitroprusside, followed by a 1 -h recovery period, on mean aortic pressure, aortic blood flow, mean left atrial pressure, heart rate, oxygen consumption, and vascular resistance in newborn $(O)$ and 3-week-old lambs (-). Data are means $\pm \mathrm{SE}$ of seven experiments in the newborn lambs, except for the oxygen consumption where it is six, and eight experiments in the 3-week-old-lambs. $C$, control (pre-infusion).

onset of nitroprusside infusion in normal animals $(13,23,25)$ and humans (27) as well as in hypertensive individuals (4, 23). This response is probably a result of baroreceptor response to the reduced arterial blood pressure. In adult patients with cardiac failure, heart rate does not usually change with nitroprusside $(7$, $8,20,21,28)$, but infants develop tachycardia (2). In our studies, the higher dose of nitroprusside resulted in an initial increase in heart rate, followed by a sudden bradycardia within 3-5 min, and then a gradual increase over $60 \mathrm{~min}$. The bradycardia was particularly marked in the younger lambs and heart rate fell below control values. The cause of this bradycardia has not been established. It is possible that the immature animal does not have as prominent a sympathetic nervous system response to the baroreflex because sympathetic innervation to the heart is incomplete (17). It is also possible that increased vasopressin release in response to the arterial hypotension and reduced left atrial pressure $(5,14)$ may be responsible for the bradycardia because vasopressin has been shown to produce bradycardia in fetal lambs (12). On the other hand, this bradycardia could also be caused by stimulation of ventricular receptors because of the low arterial pressure and the severity of the reduced venous return (22).

Cardiac output did not change significantly after infusion of 5 $\mu \mathrm{g} \cdot \mathrm{kg}^{-1} \cdot \mathrm{min}^{-1}$ nitroprusside into lambs of either age group, nor during infusion of $10 \mu \mathrm{g} \cdot \mathrm{kg}^{-1} \cdot \mathrm{min}^{-1}$ into the older lambs. However, the infusion of the higher dose in lambs during the 1st week after birth resulted in a marked fall of cardiac output, reaching a nadir at $10-15 \mathrm{~min}$, and then gradually recovering by about $60 \mathrm{~min}$ after onset of the infusion. This decrease in cardiac output is probably associated in part with reduced venous return resulting from venous pooling (29), but could be related to the fall in heart rate. Cardiac output is greatly influenced by heart rate in fetal (26) as well as neonatal lambs (Rogé, Heymann, Rudolph, unpublished observations). The cause of the increase in arterial blood pressure following cessation of the infusion has not been delineated. It could be the result of baroreflex vasoconstriction and venoconstriction which has occurred in response to the decreased arterial blood pressure, and which is unopposed by the direct local vascular effect of the nitroprusside.

Distribution of cardiac output was not altered greatly in either age group. The most important changes were a reduction in the percentage of cardiac output distributed to the kidneys and to the peripheral circulation, particularly the skin. Myocardial blood flow did not change significantly at 10 or 50 min after onset of the infusion, although arterial blood pressure was reduced. There was a trend for myocardial flow to decrease at 10 min (control, $144 \pm 18$ versus $92 \pm 16 \mathrm{ml} \cdot 100 \mathrm{~g}^{-1} \cdot \mathrm{min}^{-1}$ at 10 min), but, because of wide variation, the difference was not statistically significant (Table 3 ). It is possible that, with additional studies, this difference would be significant. Renal blood flow fell significantly with both the high and low doses of nitroprusside. There were no substantial differences in the responses in the two age groups.

These data have implications in regard to the possible use of sodium nitroprusside in treating infants with cardiac failure. In view of the reduced heart rate and cardiac output, in association with a marked fall in arterial pressure, which occur soon after infusion of large doses, it is reiterated that the initial rate of administration should be slow. Should bradycardia occur, the infusion rate should be reduced to avoid a marked fall in cardiac output because, in association with the fall in arterial pressure, 


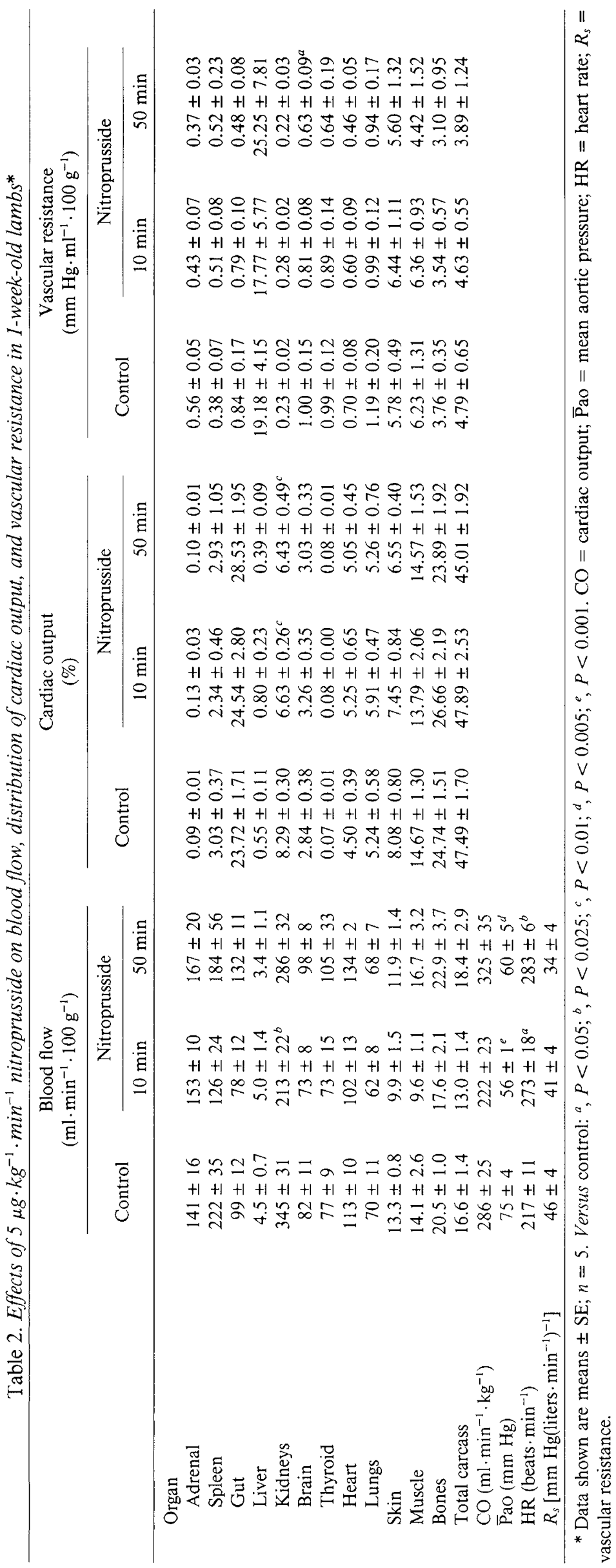




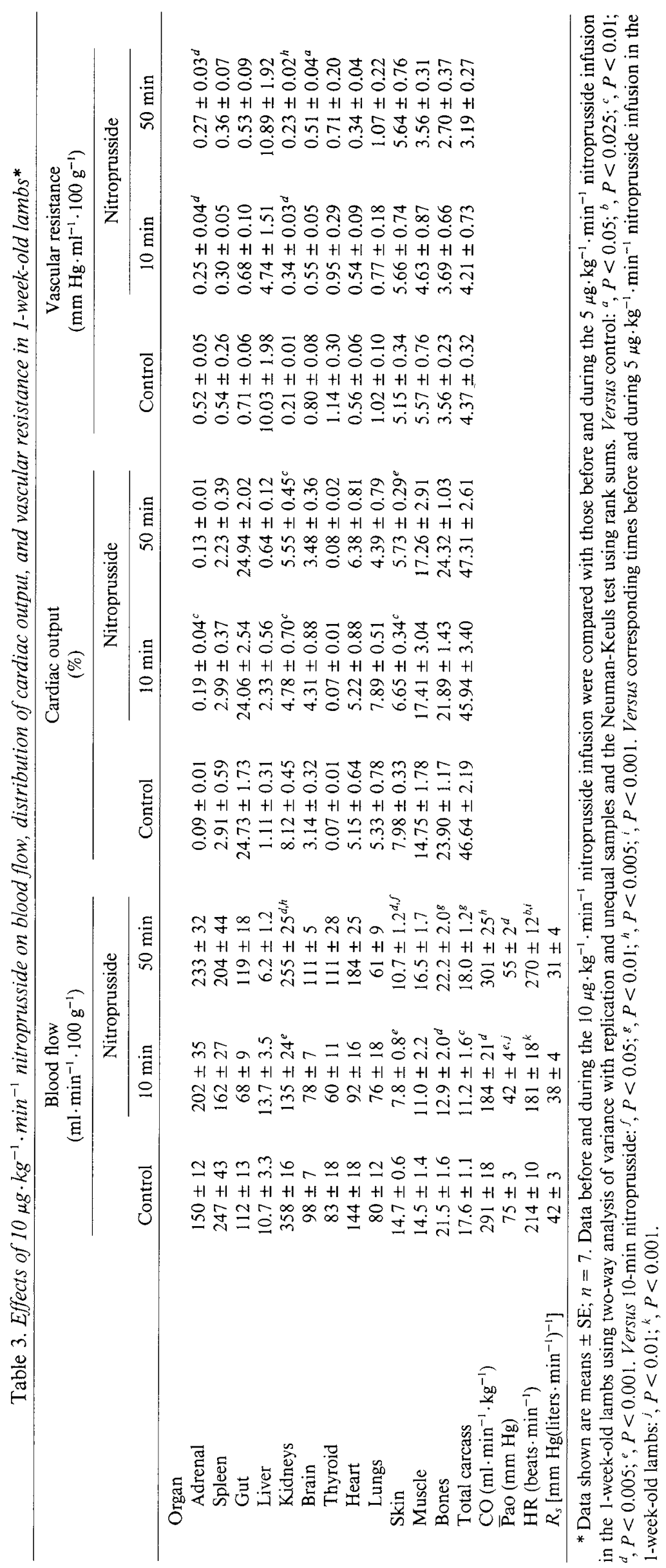


Table 4. Effects of $10 \mu \mathrm{g} \cdot \mathrm{kg}^{-1} \cdot \mathrm{min}^{-1}$ nitroprusside on blood flow, distribution of cardiac output, and vascular resistance in 3-week-old lambs*

\begin{tabular}{|c|c|c|c|c|c|c|c|c|c|}
\hline & \multicolumn{3}{|c|}{$\begin{array}{c}\text { Blood flow } \\
\left(\mathrm{ml} \cdot \mathrm{min}^{-1} \cdot 100 \mathrm{~g}^{-1}\right)\end{array}$} & \multicolumn{3}{|c|}{$\begin{array}{l}\text { Cardiac output } \\
(\%)\end{array}$} & \multicolumn{3}{|c|}{$\begin{array}{c}\text { Vascular resistance } \\
\left(\mathrm{mm} \mathrm{Hg} \cdot \mathrm{ml}^{-1} \cdot 100 \mathrm{~g}^{-1}\right)\end{array}$} \\
\hline & \multirow[b]{2}{*}{ Control } & \multicolumn{2}{|c|}{ Nitroprusside } & \multirow[b]{2}{*}{ Control } & \multicolumn{2}{|c|}{ Nitroprusside } & \multirow[b]{2}{*}{ Control } & \multicolumn{2}{|c|}{ Nitroprusside } \\
\hline & & $10 \mathrm{~min}$ & $50 \mathrm{~min}$ & & $10 \mathrm{~min}$ & $50 \mathrm{~min}$ & & $10 \mathrm{~min}$ & $50 \mathrm{~min}$ \\
\hline \multicolumn{10}{|l|}{ Organ } \\
\hline Adrenal & $129 \pm 12$ & $193 \pm 44$ & $193 \pm 25$ & $0.10 \pm 0.01$ & $0.20 \pm 0.05$ & $0.17 \pm 0.03$ & $0.64 \pm 0.09$ & $0.40 \pm 0.12$ & $0.36 \pm 0.05$ \\
\hline Spleen & $177 \pm 29$ & $105 \pm 16$ & $112 \pm 33$ & $3.44 \pm 0.55$ & $2.20 \pm 0.22$ & $1.97 \pm 0.41$ & $0.45 \pm 0.07$ & $0.53 \pm 0.07$ & $0.92 \pm 0.32$ \\
\hline Gut & $84 \pm 9$ & $72 \pm 15$ & $84 \pm 13$ & $27.05 \pm 1.97$ & $28.17 \pm 3.68$ & $29.79 \pm 2.77$ & $1.02 \pm 0.15$ & $1.10 \pm 0.42$ & $0.95 \pm 0.26$ \\
\hline Liver & $18.2 \pm 7.2$ & $18.3 \pm 12.2$ & $13.8 \pm 5.3$ & $2.26 \pm 0.78$ & $3.46 \pm 2.16$ & $2.39 \pm 1.02$ & $10.21 \pm 2.40$ & $9.70 \pm 3.07$ & $12.66 \pm 3.19$ \\
\hline Kidneys & $310 \pm 14$ & $164 \pm 17^{e}$ & $212 \pm 20^{d}$ & $11.52 \pm 0.82^{j}$ & $7.85 \pm 0.87^{a, i}$ & $9.00 \pm 0.90^{a, i}$ & $0.25 \pm 0.01$ & $0.32 \pm 0.03$ & $0.30 \pm 0.03^{8}$ \\
\hline Brain & $95 \pm 9$ & $102 \pm 15$ & $101 \pm 8$ & $3.65 \pm 0.20$ & $5.26 \pm 0.65$ & $4.54 \pm 0.39$ & $0.87 \pm 0.10$ & $0.57 \pm 0.09$ & $0.64 \pm 0.07$ \\
\hline Thyroid & $91 \pm 18$ & $87 \pm 30$ & $106 \pm 19$ & $0.07 \pm 0.01$ & $0.08 \pm 0.02$ & $0.09 \pm 0.01$ & $1.10 \pm 0.18$ & $1.01 \pm 0.38$ & $0.75 \pm 0.15$ \\
\hline Heart & $121 \pm 19$ & $101 \pm 29$ & $129 \pm 29$ & $4.90 \pm 0.29$ & $4.56 \pm 0.45$ & $5.72 \pm 0.47$ & $0.75 \pm 0.12$ & $0.73 \pm 0.18$ & $0.60 \pm 0.08$ \\
\hline Lungs & $78 \pm 26$ & $67 \pm 13$ & $63 \pm 8$ & $6.27 \pm 1.50$ & $6.87 \pm 1.30$ & $6.56 \pm 1.23$ & $1.51 \pm 0.29$ & $0.96 \pm 0.21$ & $1.18 \pm 0.23$ \\
\hline Skin & $12.7 \pm 0.9$ & $7.6 \pm 1.2^{b}$ & $8.6 \pm 1.3^{b}$ & $8.08 \pm 0.46$ & $6.14 \pm 0.73^{b}$ & $5.79 \pm 0.28^{e}$ & $6.24 \pm 0.66$ & $7.31 \pm 0.84$ & $8.55 \pm 1.39$ \\
\hline Muscle & $9.8 \pm 1.6$ & $7.4 \pm 1.1$ & $8.6 \pm 1.3$ & $11.59 \pm 1.07$ & $11.27 \pm 0.75$ & $11.58 \pm 0.72$ & $10.17 \pm 2.02$ & $7.66 \pm 1.13$ & $8.56 \pm 1.36^{i}$ \\
\hline Bones & $15.2 \pm 2.0^{g}$ & $13.8 \pm 2.4$ & $14.7 \pm 2.2$ & $19.03 \pm 1.56^{8}$ & $21.99 \pm 1.74$ & $20.55 \pm 1.37$ & $5.91 \pm 1.01$ & $4.12 \pm 0.53$ & $4.85 \pm 0.69^{h}$ \\
\hline Total carcass & $12.5 \pm 1.2^{h}$ & $10.0 \pm 1.6$ & $11.0 \pm 1.6$ & $38.72 \pm 1.51^{i}$ & $39.40 \pm 2.70$ & $37.92 \pm 1.94^{i}$ & $6.85 \pm 1.04$ & $5.55 \pm 0.70$ & $6.45 \pm 0.94^{i}$ \\
\hline $\mathrm{CO}\left(\mathrm{ml} \cdot \mathrm{min}^{-1} \cdot \mathrm{kg}^{-1}\right)$ & $228 \pm 19^{g}$ & $179 \pm 24$ & $203 \pm 22^{h}$ & & & & & & \\
\hline$\overline{\mathrm{P}} \mathrm{ao}(\mathrm{mm} \mathrm{Hg})$ & $76 \pm 4$ & $52 \pm 5^{d}$ & $60 \pm 3^{c}$ & & & & & & \\
\hline HR (beats. $\min ^{-1}$ ) & $177 \pm 12$ & $163 \pm 7$ & $227 \pm 12^{b, f, h}$ & & & & & & \\
\hline$R_{s}\left[\mathrm{~mm} \mathrm{Hg}\left(\text { liters } \cdot \mathrm{min}^{-1}\right)^{-1}\right]$ & $47 \pm 5$ & $45 \pm 7$ & $44 \pm 4$ & & & & & & \\
\hline
\end{tabular}

* Data shown are means $\pm \mathrm{SE} ; n=9$ during the control period and at $50 \mathrm{~min}, n=6$ at $10 \mathrm{~min}$. Data before and during the $10 \mu \mathrm{g} \cdot \mathrm{kg}^{-1} \cdot \mathrm{min}^{-1}$ nitroprusside infusion were compared with those before and during the $10 \mu \mathrm{g} \cdot \mathrm{kg}^{-1} \cdot \mathrm{min}^{-1}$ nitroprusside infusion in the 1-week-old lambs using two-way analysis of variance with replication and unequal samples and the Neuman-Keuls test using rank sums. Versus control: ${ }^{a}, P<0.05 ;^{b}, P<0.025 ;{ }^{c}, P<0.01 ;^{d}, P<0.005 ;{ }^{e}, P<0.001$. Versus 10 -min nitroprusside: ${ }^{f}, P<0.001$. Versus corresponding times before and during $10 \mu \mathrm{g} \cdot \mathrm{kg}^{-1} \cdot$ min $^{-1}$ nitroprusside infusion in the 1-week-old lambs: ${ }^{g}, P<0.05 ;{ }^{h}, P<0.025 ;{ }^{i}, P<0.01 ;^{j}, P<0.005$. 
coronary blood flow could be seriously reduced. A second potential disadvantage in the use of this agent is the reduced renal blood flow. This could have serious adverse effects in an infant who already has cardiac failure with limited renal function. The mechanism responsible for the reduced renal blood flow has not been established. It could be merely a result of the fall in arterial blood pressure below the range of effective autoregulation, or it could result from a renin-angiotensin mechanism induced by the fall in arterial pressure. Whatever the cause, it merits careful attention if infants are to be treated by afterload-reducing agents.

\section{REFERENCES AND NOTES}

1. Armstrong PW, Walker DC, Burton JR, Parker JO 1975 Vasodilator therapy in acute myocardial infarction. A comparison of sodium nitroprusside and nitroglycerin. Circulation 52:1118

2. Beekman RH, Rocchini AP, Rosenthal A 1981 Hemodynamic effects of nitroprusside in infants with a large ventricular septal defect. Circulation $64: 553$

3. Benzing G, III, Helmsworth JA, Schrieber JT, Loggie J, Kaplan S 1976 Nitroprusside after open-heart surgery. Circulation 54:467

4. Bhatia SK, Frohlich ED 1973 Hemodynamic comparison of agents useful in hypertensive emergencies. Am Heart J 85:367

5. Brennan JLA, Malvin RL, Jochim KE, Roberts DE 1971 Influence of right and left atrial receptors on plasma concentration of $\mathrm{ADH}$ and renin. Am J Physiol 221:273

6. Brodic BR, Chuck L. Klausner S, Grossman W, Parmley W 1976 Effects of sodium nitroprusside and nitroglycerin on tension prolongation of cat papillary muscle during recovery from hypoxia. Circ Res 39:596

7. Brodie BR, Grossman W, Mann T, McLaurin LP 1977 Effects of sodium nitroprusside on left ventricular diastolic pressure-volume relations. J Clin Invest 59:59

8. Chatterjee K, Parmley WW, Ganz W, Forrester J, Walinsky P, Crexells C, Swan HJC 1973 Hemodynamic and metabolic responses to vasodilator therapy in acute myocardial infarction. Circulation 48:1183

9. Cohn JN, Franciosa JA 1977 Vasodilator therapy of cardiac failure. N Engl J Med 297:254

10. Guiha NJ, Cohn JN, Mikulic E, Franciosa JA, Limas CJ 1974 Treatment of refractory heart failure with infusion of nitroprusside. N Engl J Med 291:587

11. Heymann MA, Payne BD. Hoffman JIE, Rudolph AM 1977 Blood flow measurements with radionuclide-labeled particles. Prog Cardiovasc Dis 20:55

12. Iwamoto HS, Rudolph AM, Keil LC, Heymann MA 1979 Hemodynamic responses of the sheep fetus to vasopressin infusion. Circ Res 44:430

13. Johnson CC 1929 The actions and toxicity of sodium nitroprusside. Arch Int Pharmacol 35:480

14. Johnson JA, Moore WW, Segar WE 1969 Small changes in left atrial pressure and plasma antidiuretic hormone titers in dogs. Am J Physiol 21 7:210

15. Klopfenstein HS, Rudolph AM 1978 Postnatal changes in the circulation and responses to volume loading in sheep. Circ Res 42:839

16. Kuipers JRG, Sidi D, Heymann MA, Rudolph AM 1982 Comparison of methods of measuring cardiac output in newborn lambs. Pediatr Res 16:594

17. Lebowitz EA, Novick JS, Rudolph AM 1972 Development of myocardial sympathetic innervation in the fetal lamb. Pediatr Res 6:887
18. Lister G, Hoffman JIE, Rudolph AM 1974 Oxygen uptake in infants and children. A simple method for measurement. Pediatrics 53:656

19. Lister G, Walter TK, Versmold HT, Dallman PR, Rudolph AM 1979 Oxygen delivery in lambs: cardiovascular and hematologic development. Am J Physiol 237:H668

20. Miller RR, Vismara LA, Williams DO, Amsterdam EA, Mason DT 1976 Pharmacological mechanisms for left ventricular unloading in clinical congestive heart failure. Differential effects of nitroprusside, phentolamine, and nitroglycerin on cardiac function and peripheral circulation. Circ Res 39:127

21. Miller RR, Vismara LA, Zelis R, Amsterdam EA, Mason DT 1975 Clinical use of sodium nitroprusside in chronic ischemic heart disease. Effects on peripheral vascular resistance and venous tone and on ventricular volume, pump and mechanical performance. Circulation 51:328

22. Öberg B, Thorén P 1972 Increased activity in left ventricular receptors during hemorrhage or occlusion of caval veins in the cat. A possible cause of the vaso-vagal reaction. Acta Physiol Scand 85:164

23. Page JH, Corcoran AC, Dustan HP, Koppanyi T 1955 Cardiovascular actions of sodium nitroprusside in animals and hypertensive patients. Circulation 11:188

24. Parmley WW, Chuck L, Chatterjee K, Swan HJC, Klausner SC, Glantz SA, Ratshin RA 1976 Acute changes in the diastolic volume relationship of the left ventricle. Eur J Cardiol 4:105

25. Rowe GG, Henderson RH 1974 Systemic and coronary hemodynamic effects of sodium nitroprusside. Am Heart J 87:83

26. Rudolph AM, Heymann MA 1976 Cardiac output in the fetal lamb: the effects of spontaneous and induced changes of heart rate on right and left ventricular output. Am J Obstet Gynecol 124:183

27. Schlant RC, Tsagaris TS, Robertson RJ 1962 Studies on the acute cardiovascular effects of intravenous sodium nitroprusside. Am J Cardiol 9:5 I

28. Sidi D, Kuipers JRG, Heymann MA, Rudolph AM 1983 Effects of ambient temperature on oxygen consumption and the circulation in newborn lambs at rest and during hypoxia. Pediatr Res 17:254

39. Tinker JH, Michenfelder JD 1976 Sodium nitroprusside: pharmacology, toxicology and therapeutics. Anesthesiology 45:340

30. Winer BA 1971 Statistical Principles in Experimental Design. New York, McGraw Hill

31. Zar JH 1974 Biostatistical Analysis. Englewood Cliffs, Prentice-Hall, Inc

32. Zelis R, Flaim SF, Moskowitz RM, Nelis SH 1979 How much can we expect from vasodilator therapy in congestive heart failure? (editorial). Circulation 59:1092

33. This research was supported by United States Public Health Service Grant HL23681, a NATO grant awarded by the Organization for Advancement of Pure Research-Z. W. O. (J. R. G. K.), and a grant awarded by the French Government (D. S.)

34. Current address: University of Groningen, University Hospital, Department of Pediatric Cardiology, Oostersingel 59,9713 EZ Groningen, The Netherlands.

35. Current address: Service de Cardiologie Infantile, Hôpital Necker-Enfants Malades, Rue Sèvres, Paris 75015, France.

36. Requests for reprints should be addressed to: A. M. Rudolph, M.D., 1403HSE, University of California, San Francisco, California 94143.

37. The authors gratefully acknowledge the skillful technical assistance of Carl McWatters, Bruce Payne, and Christine Roman, and the secretarial help of Kathy Storer, Eveline Elmers, and Han Marra.

38. Received for publication March $31,1983$.

39. Accepted for publication July 19, 1983. 